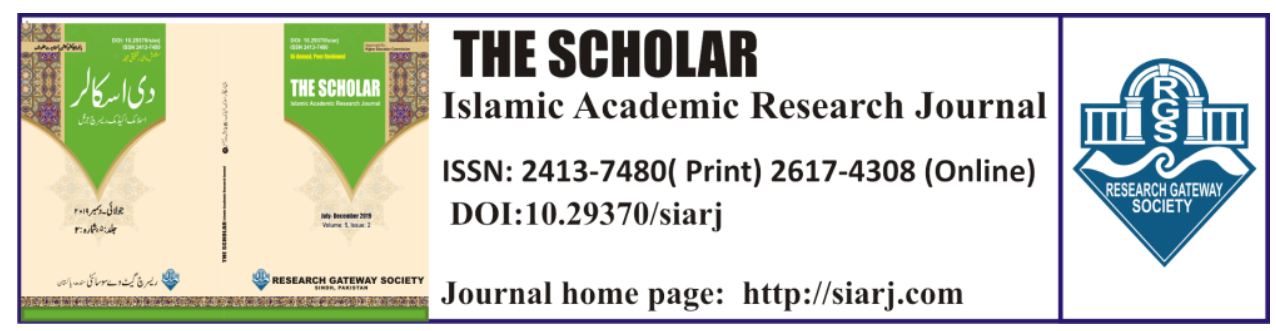

\title{
ISLAMIC LEGAL PRINCIPLES: THEIR ROLE AS TO COMPLEMENT NOTICEABLE GAPS IN THE CODIFIED LAWS IN PAKISTAN
}

\author{
1. Dr. Aamir Abbas \\ Assistant Professor of Law, government \\ college university, Faisalabad \\ Email: aamirabbas1981@hotmail.com \\ ORCID IID: \\ https://orcid.org/0000-0003-1350-9650
}

\section{Dr. Samza Fatima}

Assistant Professor, University

Gillani Law College Bahauddin

Zakariya University, Multan,

Pakistan

Email: samza.fatima@bzu.edu.pk

ORCIID IID:

http://orcid.org/0000-0002-8689-8629

\section{Dr. Muhammad Bilal}

Assistant Professor, University Gillani Law College Bahauddin Zakariya

University, Multan, Pakistan

Email: mbilal@bzu.edu.pk

\section{ORCID IID:}

http://orcid.org/0000-0002-5232-6075

To cite this article:

Abbas Amir, Faiz, Samza Fatima, and Muhammad Bilal. "ISLAMIC LEGAL PRINCIPLES: THEIR ROLE AS TO COMPLEMENT NOTICEABLE GAPS IN THE CODIFIED LAWS IN PAKISTAN.” The Scholar-Islamic Academic Research Journal 6, No. 1 (March 03, 2020)P: 24-38.

To link to this article: https://doi.org/10.29370/siarj/issue10ar2

\begin{tabular}{|c|c|}
\hline Publisher & $\begin{array}{l}\text { The Scholar Islamic Academic Research Journal } \\
\text { Vol. 6, No. } 1 \text { || January -June } 2020 \text { || P. 24-38 } \\
\text { Research Gateway Society }\end{array}$ \\
\hline DOl: & 10.29370/siari/issue10ar2 \\
\hline URL: & https://doi.org/10.29370/siarj/issue10ar2 \\
\hline License: & Copyright c 2017 NC-SA 4.0 \\
\hline Journal homepage & www.siari.com \\
\hline Published online: & $2020-26-03$ \\
\hline
\end{tabular}
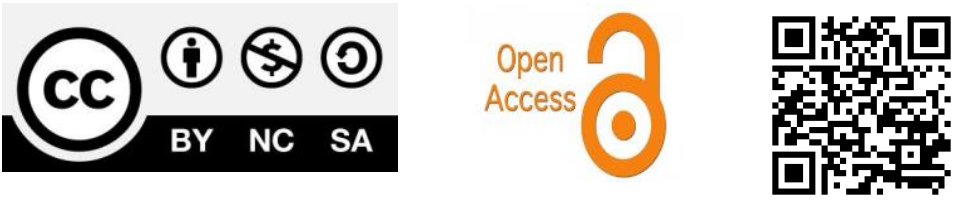
THE SCHOLAR (January- June 2020)

\title{
ISLAMIC LEGAL PRINCIPLES: THEIR ROLE AS TO COMPLEMENT NOTICEABLE GAPS IN THE CODIFIED LAWS IN PAKISTAN
}

\author{
Aamir Abbas, Samza Fatima, Muhammad Bilal
}

\begin{abstract}
:
Islamic considerations can be a useful tool to complement laws where statutory legislation comes short of covering newly-emerging propositions supposed to be covered by the laws of the land. This research works is based on the concept of equity in the UK which plays a moderating role in the legal framework of the UK. Islamic considerations and complementary sharia principles are also concomitant in the Saudi legal system. This article encompasses an analysis of sharia principles and their role to supplement laws in Pakistan. In addition, it also sheds light on the comparable analysis of İștịhṣān in Sharia Law with its analogous doctrine of equity in the UK. The methodology used to conduct study for the article is doctrinal employing exploratory philosophy along with inductive approach. The conclusions drawn from the discussion of this article would have a significant impact on the on-going debate of Islamic Legal Principles and would have a significant contribution in the existing literature. Moreover, the discussion and theories debated in the article will provide a base for the future studies in the relevant area.
\end{abstract}

KEYWORDS: Islamic legal principles, Islamic concept of equity, İștịịṣān, Principles of İștịṣlā, English concept of equity

\section{INTRODUCTION}

There are various misunderstandings about the application of Sharia jurisprudence in the west where it is called as primitive and something 
redundant and impracticable. This is, in fact, a misconception and lack of knowledge of these parts of the world about the Sharia law. However, its influence and identity has been established in the recent times where we see the significance of sharia law principles gaining importance and providing alternative solutions to the failing norms and principles in the legal frameworks of the world. ${ }^{1}$ Some principles of sharia such as shariacompliant business practice, Islamic banking, Islamic financial system, insurance policies and other civil laws principles have gained recognition and popularity after the increase of petroleum prices in the world because of the dependency factor of the west on the oil producing Muslim countries.

Now, many Muslim scholars such as Imran ahsan khan niazi and Makdisi have refuted misunderstandings in the west about sharia law providing a detailed dictum of the Islamic law. They are of the view that Islamic law has been developed by the well-versed jurists of sharia employing

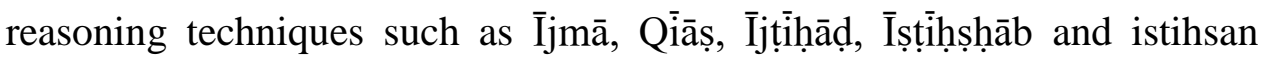
with their confirmation from the primary sources (Quran and Sunnah) of Islamic laws. Makdisi also opines that western criminal, contractual and tenancy laws are influenced by the sharia principles on fundamental counts. He points out that some core features of English law such as trial by jury, action of debt, assize of novel dissesin, legal precedent were borrowed from the sharia law. Moreover, characteristics of English laws such as rescission, (Īqālāḥ), Act of God (āfăt șāmāwìyāḥ), destruction of

\footnotetext{
${ }^{1}$ Al-Syathibi . Al- Muwafaqat fi Ushul al- Shariah, Riyad : Maktabah alRiyad al- Hadith
} 
purpose (ịștịhāāāh āl țānfị̣̣̂h) and farce majeure in contractual obligations were also developed by the Islamic jurists. ${ }^{2}$

Moreover, the concept of transferring the property or subject matter of the contract upon immediate conclusion of the contract was also introduced by the Islamic jurists, which the concept was adopted after the reign of King Henry 11 by the act of debt. Another scholar, Henry Cattan finds that the institution of trust in English law is borrowed from the Islamic law concept of wāqf (endowment). ${ }^{3}$ Also, modern criminal law principles such as, a person is vested with a right to abstain from testifying where he/she is being incriminated himself or herself, prohibition of hearsay evidence in trial, equality of law (equality before law and equality of person have come into English law from the Islamic criminal law principles. So, Islamic law is not impracticable and primitive as is viewed by the west. It cherishes deep and rich characteristics which are able not only to cover newly-new cropped up propositions but also has the ability to influence other legal systems in the world.

Scholars also view many similarities between the two legal systems. For instance the concept of judge as an impartial person to judge between the disputant parties is analogous to Qazi in shariat courts. Moreover, English law concept of fiduciary duties is quite analogous to the concept of āmānā

\footnotetext{
2 al- Zarqā, Mstafā. 1968. al-Madkhal al-fiqhī al-'āmm. 10th ed. 3 vols. Damascus: Matba'at Tirbīn.

${ }^{3}$ Bentham. J. (1950). The Theory of Legislation, trans. R. Hidreth, ed. C. K. Ogden, Routledge \& Kegan Paul Ltd.
} 
(trust) in Sharia law. All in all, in terms of the genesis of these two legal systems, they share similarity for being borne out of the customary law. ${ }^{4}$

\section{THE CONCEPT OF EQUITY IN ENGLISH LAW}

The principle of equity evolves over a period of time which means employing the principles of natural justice, good conscious and fairness in the absence of clear rules. The regulations of 1781 has provided for exercising good conscious, fairness, equity of the judges in the absence of law or specific rules. It is also considered as a replica principle of the doctrine of 'epieikeia' propounded by Aristotle whom the principle aims to extend flexibility to the codified law where it intends to cause injustice. This was borne out of the necessity caucused by the deficiencies in the common law. ${ }^{5}$

The concept of equity is widely recognized as being flexible and vesting law making powers to judges to apply their good conscious and rules of natural justice and fairness. Equity is meant to serve the purposes of justice and comes to rescue law when it intends to cause injustice by following the laws in letters. The concept of equity has complemented common law by creating rights, providing remedies which were otherwise not available due to the rigidity of laws. For instance, remedies such as

\footnotetext{
${ }^{4}$ Emil Brunner, 'Justice and the Social Order', trans. M. Hottinger, (Lutterworth Press, 1945)

${ }^{5}$ William Warwick Buckland, 'Some Reflections in Jurisprudence', (Cambridge University Press, 1945)
} 
Islamic legal principles: their role as to complement noticeable gaps in the codified laws in Pakistan

specific performance of contracts, recession, rectification and injunction were the outcome of equitable justice based the principles of equity. ${ }^{6}$

\section{THE CONCEPT OF ISTIHSAN IN ISLAM}

There are various tools of Islamic law sources such as, Qiāạ (analogy), Ijma (consensus), Ijjṭihạạ (an exertion made to interpret the will of Allah in accordance with the injunctions of Quran and Sunnah) and ūrf (custom) which have afforded creativity and development to the jurisprudence in Islamic law. There are reasoning methods which have also helped Islamic law to develop employing changes from time to time. İștịhṣān is a source of Islamic law which allows incorporation of new rights and remedies to Islamic laws. ${ }^{7}$ Al Baji said that İștịhṣān as was used by Maliki school of jurists,

"Means to seek the opinion that is based on the stronger of two indications in the text."

It is an instrument whereby extension of laws is reckoned with the social needs and other requirements of the local conditions. This also allows broadening the scope of analogy in order to extend flexibility to laws by the argument of minore ad majus, majure ad minus and a fortiori. ${ }^{8}$

Thus, this source is intended to reconcile remedies and reliefs to other sources of Islamic law. This very characteristic of Istihsan keeps in view the spirit and essence of law instead of following laws strictly with their

${ }^{6}$ Giorgio Del Vecchio, 'Philosophy of Law', trans. T. O. Martin. (Catholic university of America Press, 1953)

${ }^{8}$ Jerome Hall, 'Foundations of Jurisprudence', (The Bobbs-Merrill Co. Ins., 1973) 
Islamic legal principles: their role as to complement noticeable gaps in the codified laws in Pakistan

intended outcome of incomplete justice. This aims at correction of laws where they fail to serve the purposes of justice. İștịhṣān is an analogous to the term, equity in English law which is meant for equitable justice and correcting incomplete justice. However, one striking difference between the two complementary doctrines is their authority to derive guidance. For example, Equity derives its justification and guidance from the natural rights and from the concept of justice beyond codified laws. Contrary to this, the concept of Îsțịhṣān relies on the injunctions of Quran and Sunnah. As such, English law hypothesises that a fiduciary relation of the principal and the agent tends to give rise to agency problems and hence, requires an accountability mechanism whereas, the Islamic law requires from the agent not only to be faithful and honest to the assets and property of the principal but he/she is also answerable for his dishonesty to Allah. ${ }^{9}$

The Islamic scholars are now more prone to the rational interpretation of the texts and keeping in sight the modern and geographical conditions. This trend has led the Islamic scholars walking away from the supernatural interpretations of the texts, thus, paving the way for bridging the gaps between the two systems. As such, both the principle of equity and the principle of İștịṣān are similar to the extent of their necessity to play a supplementary role in providing an equitable justice. ${ }^{10}$

Imam Malik was an Islamic jurist who employed the technique of İștịịṣān in rendering his legal opinions on particular propositions (Fatwa). In later

\footnotetext{
${ }^{9}$ Roscoe Dorsey, 'Roman Sources of Some English Principles of Equity and Common Law Rules' (1938) 8(12) The American Law School Review, 1233

${ }^{10}$ Hafiz Abdul Ghani, 'A Study of the History of Legal Maxims of Islamic Law’ (2012) 1(2) International Journal of Arts and Commerce, 90-99
} 
Islamic legal principles: their role as to complement noticeable gaps in the codified laws in Pakistan

years, many Islamic jurists and judges used this technique while interpreting and giving opinions on some legal issues, and thus, this source of law got recognition with the manifestation of its utility and benefits in the development of jurisprudence in Islamic law. For instance, Yahya-ibnYahya, the qazi ul Qaza (the chief judge of the state), from Spain had his many legal opinions based on the principle of İștịhṣān. Another notable Islamic jurists and chief judge of the time Asad ibn Furat decided upon problems brought by the Iraqi people on the basis of Istihsan. ${ }^{11}$

With striking instances of employing the technique of İștịhṣān, jurists opine that a worker owes responsibility or otherwise liability for the damage and destruction of an article handed over to him/her for the intended work. It is important to explain here that as a general rule the worker is a trustee of the deposit where he/she is not liable for any loss done to the deposit but imposition of liability based on the public interest is demanding in order to ensure the protection of assets of the owners. This is imperative to establish liability for the sake of the protection of the property otherwise it is undoubtedly difficult to establish negligence on their part where they could be held liable. The Maliki school of thought argues that the liability for the loss and destruction of the property must be fixed on the worker until it is proved that the loss and destruction was caused by their negligence. Hazrat Ali (R.A) established that the worker will be liable for the loss or destruction of the things even if he/she claims exemption on the basis of negligence. Thus, the fourth caliph transformed

\footnotetext{
${ }^{11}$ Coulson James, “Law and Religion in Contemporary Islam” (1978) 29, Hastings Law Journal, 1447-1457
} 
Islamic legal principles: their role as to complement noticeable gaps in the codified laws in Pakistan

the depository contract into a guarantee contract by fixing the liability on the worker even though it was caused by the negligence on his/her part. ${ }^{12}$

During the era of Hazrat Umar (R.A.), the caliph suspended the punishment of the amputation of hands (Hadd Punishment provided in the text) for the crime of theft during the time of famine. This order came keeping in sight the public interest, equity and good conscious. Here the positive law concept/Literalist view has been suspended for the protection of the interests of public. Kāmāli, a famous Islamic jurists also discussed the strength of İstịhṣhāan in the development of jurisprudence in Islamic law as he says that the Șāhāāạ, (the companions and Ṭābieeen, the successors) were not the believer of positive law theory rather they kept in sight the objectives and purposes of justice and Sharia while giving ruling on matters of public interests. ${ }^{13}$

The intent of this principle has been inferred from the Ayat (Al Baqara $2: 185)$

"God intends facility (legal mitigation) to you, and He does not want to put you in hardship"

For example, eating something which is declared as haram (prohibited) is not sinful when it is eaten at a time of a life is in risk of death.

There is a Hadith which is relied upon for the validity of İștịhṣān which reads as:

\footnotetext{
${ }^{12}$ Mohammad Hashim Kamali, 'Legal maxims and the other genres of literature in Islamic Jurisprudence’ (2006) 20(1) Arab Law Quarterly, 77101

${ }^{13}$ Saim Kayadibi, and Ijtihad by Ra'y: The Main Sources of Inspiration Behind Istihsan. (2007) 24(1) The American Journal of Islamic Social Sciences, 76
} 
Islamic legal principles: their role as to complement noticeable gaps in the codified laws in Pakistan

"No harm shall be inflicted and accepted in Islam."

Moreover, oral testimony is a recognised form of an evidence in sharia law, however, in the modern era, where modern techniques and tools of testimony such as, photography, deoxyribonucleic acid DNA, forensic evidence and other scientific based evidences are more reliable and undeniable evidences to be accepted. İștịhṣān prioritizes such evidences on the basis of its being more truthful and reliable. Also, based on the principle of İștịhṣān, according to the Ḥānāfī school of thought, the ancillary benefits or rights of a wāqf property should deem to be transferred with the conclusion of the contact otherwise the purpose of the contract would be frustrated. Îștịịṣān also allows creation of exception in a general rule where the ends of justice are not being met. All in all jurists have benefited from the technique of İsțịhṣān in order to develop jurisprudence where law is silent or inadequate to correct wrongs. ${ }^{14}$

Based on the above discussion, Islamic considerations by the use of legal reasoning methods have a vital role to play in correcting shortcomings and mistakes in the law. Other than the primary and secondary sources of Sharia law, Islamic maxims are complementary to the statutory laws. ${ }^{15}$ These maxims have developed over a period of time to the conformation of primary and secondary sources and understood significant legal virtues as claimed by Imam al Ṣhāẫ that

'Who employees legal reasoning technique (İștịịșān), attains the authority to legislate'.

${ }^{14}$ Mahajan. V. D., Jurisprudence. Irfan Law Book House

${ }^{15}$ Coulson Noel James, ' Conflicts and Tensions in Islamic Jurisprudence' (The University of Chicago Press, 1969) 
In Sharia, basic rule called Qā īị̂ā (foundation) is taken into consideration for dealing with proposition where there is no clear rule available in the text. However, this foundation rule may not a permanent rule as they work under the subjugation and operation of the primary sources. Therefore, Islamic legal maxims do not have binding effects upon the adjudication of problems and issues but they function as a persuasive tool of solving problems. Professor Kāmāli has discussed legal maxims into five main categories, which can also be found in the English law by their meanings. 16

Contractarian theory of law posits the incompleteness of rules having binding effects on the contracting parties, which the theory underpins more flexing rules to be employed in order to meet the ends of justice . This is where these Islamic legal maxims derived from the intents of the primary sources come to rescue the text / hard law. Originally, laws in today's world are influenced by the legal maxims. Some Islamic jurists are of the view that Istihsan cannot be a replica principle of equity is English law. As such, there is another term used in Islamic sources of law, Istislah, which is more liberal in its meanings and takes into account the public interest while interpreting the intent of the Lawgiver. Both Istihsan and Istishla together used to correct mistakes in the law can be a similar to the doctrine of equity in English law. In addition to this, the doctrine of permissibility (ỉbāḥā) in the sharia law allows innovation and adaptability to changing conditions where these do not deviate from the main intent of

\footnotetext{
${ }^{16}$ Mohammad Hashim Kamali, 'Equity and Fairness in Islam' (2005) Fundamental Rights and Liberties in Islam Series: Volume 3
} 
The Scholar Islamic Academic Research Journal

Vol. 6, No. 1 || January-June 2020 || P. 24-38

https://doi.org/10.29370/siarj/issue10ar2

sharia and hence, playing a complementary role to achieve the objectives of sharia. ${ }^{17}$

The need of the hour is to afford justifiable freedom of expression and democratization of society where Muslim scholar may ponder upon the changing conditions of today and provides solutions to the rigidity of legal rules. It is equally important to make efforts in order to explain and interpret sharia law under the guidance of the primary sources for converging sharia law with the erstwhile codified law in Pakistan for its complimentary role to play. This is important so as to avoid two conflicting systems where the cohesiveness and consistency of decisions of courts are being compromised. ${ }^{18}$

\section{THE CONCEPT OF IJTIHAD IN ISLAM}

The considerate Islamic imperatives meet worldly wise snags is reached through the procedure of Ijtihad. Broadly speaking, ijtihad has been of three kinds: ijjṭihāọ mūṭlāq also called 'absolute disciplined judgement'; ijj̣̣hhạạ fî̀'l Șhāriāḥ also called 'disciplined judgement within the system of a particular Divine law, e.g., the Quran'. By ijtihad mutlaq, the principles of a specific religion, or school of Islamic jurisprudence, were determined. In the community of Sunni school of thought, it has been the prevailing view, so far, that the four great mūjțāịịīin, who were qualified to establish, restate or reform an a basic legal principle, were the four great imams namely, Abu Hanifa, Malik ibn Anas, al-Shafii and Ahmad bin

${ }^{17}$ John Makdisi, 'Legal Logic and Equity in Islamic Law' (1985) 33(1), The American Journal of Comparative Law, 63-92

${ }^{18}$ Imran Ahmed Khan Nyzee, 'Theories of Islamic Law: The Methodology of Ijtihad' 
Hanbal, along with some other fellows, and that after them the right of ijtihad mutlaq terminated. ${ }^{19}$

In the recent past, in minimalist approach, was it possible for a new school of fiqh to come into existence within the framework of the sharia of Islam. Irrevocable, and ostensibly unfailing, ijmā had been reached on ijṭ̂ịạạ̣ mūṭlāq. Hence, later mūjṭāhịị̄ūn were doctrinally constrained to exercise

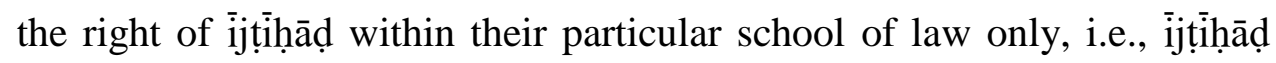
fi'l maddhab, the right of disciplined judgement within the framework of an existing school and its agreed, unalterable principles. In addition to these, they were also called mūqāllịịun, or imitators, were the principle, or roots, were concerned, and mujtahidan upon the furu, or branches. Subsequently, the system and the schools within it were regarded as complete in essentials and the only degree of ijtihad approved was ijtihad fi'l-fatwa, or disciplined judgement on a specific point of law, sometimes described as ijjṭihāạ fî̀'l-māṣā'ìl, or disciplined judgement on a particular matter. $^{20}$

It is pertinent to mention here that, mūjṭāhịịḍ̄n of this class were required to be mūqāllị̂ūn regarding the usul and the furu, i.e., the principles and their consequences or, to put it another way, the formal legal sources and the substantive law. As far as the new problems to continue to arise, irrespective of whether one holds the view that human nature has remained

\footnotetext{
${ }^{19}$ Imtiaz Ahmed Khan Nyzee, Islamic Jurisprudence (Usul al-Fiqh). International Institute of Islamic Thought and Islamic Research Institute, (2006).

${ }^{20}$ Yazbeck Haddad Yvonne, "Sayyid Qutb: Ideologue of Islamic Revival," in John L. Esposito (ed.), Voices of Resurgent Islam. (New York: Oxford University Press, 1983).
} 
The Scholar Islamic Academic Research Journal

Vol. 6, No. 1 || January-June 2020 || P. 24-38

https://doi.org/10.29370/siarj/issue10ar2

unchanged or not, this form of ijṭihạạd is, permitted, even in conservative theory. Henceforth the confusion about whether the gate of ijtịhāọ is open or not. It is significant not to lose sight of the fact that ijṭihāẹ is disciplined judgment upon the meaning of the Quran and Sunnah and not judgment, disciplined or otherwise, which has its premises outside the sources of Islamic thought. $^{21}$

Therefore, an ỉjṭ̂hhāẹ should be based upon the ūṣūl-āl-fīqḥ, or formal legal sources of Islamic Jurisprudence. However, it has been observed, that factors making error can be distinguished and identified in the existing methodology for interpreting the Quran, Sunnah, Qiyas and ijma. Likewise, an error in interpreting the usul should, unavoidably, vitiate the degree of accuracy that can be claimed for furu conclusions and the error is liable to be even more pronounced in a fatwa. Therefore the protection of isma, that collective ijṭihạạ should afford, is lost. It is true that individual ijṭihạạ has always been regarded as zāmn, or purely presumptive conjecture, but collective ijṭ̂hạạ is not so regarded, being held to be protected from error. Yet, quite apart from the essential limits that must be placed on the freedom from error, i.e. dependability, of collective ijṭ̂ị̄ạḍ or ijmā. ${ }^{22}$

The contrivance of ijtịhāẹ is unable to accomplish its tasks until the roots and branches of Islamic legal thought have been pruned, and, where necessary, pollard. For this purpose, it is essential that these basic concepts

${ }^{21}$ Coulson Noel James. "Islamic Law". In the New Encyclopaedia Britannica. Vol. 9, Macropaedia, (15 ${ }^{\text {th }}$ edition. Chicago, 1974) $938-943$

${ }^{22}$ Georghios Pikis, An analysis of the English Common Law, Principles of Equity and their Application in a former British Colony, Cyprus. Series: Nijhof Law Specials, Volume: 93, (2016). 
of Islamic legal thought be re-examined, asserting and recalling some of the overall, general considerations which must govern the exercise of ijtihad by those regarded as competent so to do. In arriving at this stage, the key is discernible to achieving, as nearly as possible, the limited 'isma, permissible within the context of tauhid ("Oneness of Allah"). Only when we have lessened, and continue to lessening, the factors making for error and reducing 'isma in our methodology will the system of fiqh established by human minds adequately apprehend sharia. Only in such circumstances can our legal averages and obligations direct Islamic society along the Divine highway and to true individual and collective submission to the commands of Allah. ${ }^{23}$

By concluding the debate it can be said that perpetual ijṭ̂hāọ was our protection against error in considering șhāriāh and that continuous ijtihad was the means for achieving relative 'ișmā in our understanding of the concept of word Allah and the way of the Prophet, the only significant command is that ijṭịạạ should be operating rightly to steer the Islamic society; which for sure, implies that the machinery for prospectively ascertaining the collective ijtihad of ijma must be sufficient and, thus, eliminate the element of zāmn, or subjective conjecture, inherent in individual ijṭ̂ihāạ.

\section{CONCLUSION}

This article has addressed issues concerning the misconceptions about the Islamic law and its applicability in Pakistan where it can contribute

\footnotetext{
${ }^{23}$ Imran Ahmed Khan Nyazee, 'Jurisprudence. Advanced Legal Studies Institute’ (Federal Law House, 2015)
} 
The Scholar Islamic Academic Research Journal

Vol. 6, No. 1 || January-June 2020 || P. 24-38

https://doi.org/10.29370/siarj/issue10ar2

towards strengthening the legal frameworks on various categories of laws including its interpretation and implementation. Pakistan is an Islamic state where the Islamic laws has a predominant role to play in reforming laws, therefore, it underpins shedding lights on more flexible tools of sharia law such as iṣțịhṣān, Ijma and istisla in complementing codified laws. By analysing the principles of İștịhṣān, ijma and iṣțiṣlā, it has been expected that these sharia law tools may function to meet the ends of justice analogous to the functions of equity in the UK. The study conducted for this article is exploratory as it explores the ways to interlink and create harmony among the analogous provisions of Islamic legal principles and the concept of equity in English legal system. The tools used to interpret the codified laws in order to fill gaps are "the literal, golden and mischief rues of interpretation'. The discussion of this paper provides a base for future studies in to minimise the gaps among Islamic legal principles and the codified laws in Pakistan.

\section{(ब)(®)}

This work is licensed under a Creative Commons

Attribution-NonCommercial-ShareAlike 4.0 International (CC BY-NC-SA 4.0) 